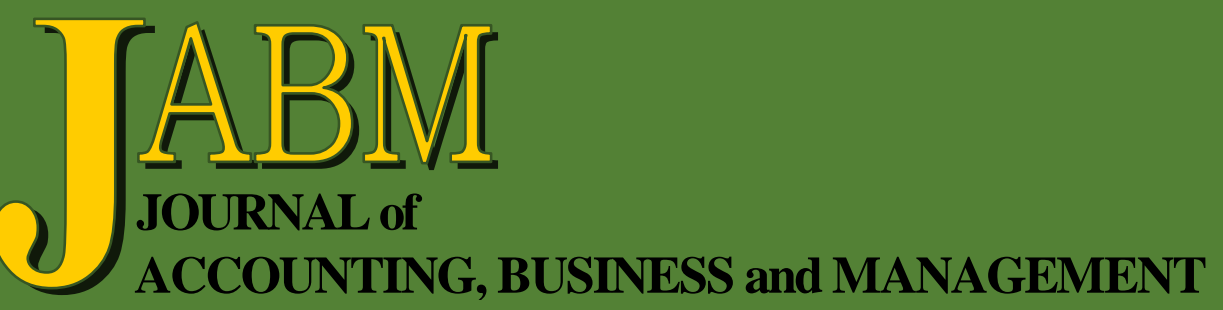

An Analysis of Management Accounting System Development from the Structuration Theory Viewpoint

Anthony Moung Yin Chan, Paul Lo and Kong Ng

Impact of Total Asset Turnover Ratios on Equity Returns: Dynamic Panel Data Analyses

Jeanne-Claire Patin, Matiur Rahman and Muhammad Mustafa

The Impact of Audit Committees on US Nonprofit Organizations'

Governance

Husam Abu-Khadra

Implicit Taxes Amid Race to the Bottom in a Global Tax Game

Igor Semenenko, Junwook Yoo and Parporn Akathaporn

The Adoption of Financial Accounting Standards for Small Medium Enterprises by Muslim Entrepreneurs

Muslichah, Sunarto, Anang Amir Kusnanto, Sri Indrawati and Hariyanto

The Impact of E-Procurement Systems in the Biomedical Industry

A. Seetharaman, Nitin Patwa, Simon Lai Koek Wai and Ahammed Shamir

After-Tax Discounting: A Research Edge

Hongtao Guo

Rules-Based Accounting Standards and SEC Enforcement

Devon Baranek 
Journal of Accounting, Business and Management (JABM) vol. 27 no. 1 (2020) 19-29

\title{
Impact of Total Asset Turnover Ratios on Equity Returns: Dynamic Panel Data Analyses
}

\author{
Jeanne-Claire Patin* \\ Matiur Rahman ${ }^{\dagger}$ \\ Muhammad Mustafa
}

\begin{abstract}
This paper is an empirical exploration of the impact of total asset turnover ratios on stock returns of 1961 US public firms in different types of industries from 2001 to 2015. Stock prices are significantly influenced by operating performance of a company in efficiently utilizing its assets. For that matter, operating efficiency (as measured by total asset turnover ratio) plays a role in portfolio investment decisions. Pedroni's heterogeneous panel co-integration procedures, associated bivariate error-correction model (ECM), dynamic ordinary least squares (DOLS) and generalized method of moments (GMM) are applied. Both stock returns and total asset turnover ratios in levels are nonstationary with I (1) behavior. Subsequently, both variables are found cointegrated. The panel ECM estimates suggest convergence of variables toward long-run equilibrium at moderate pace with short-run interactive positive feedback effects. Again, both DOLS and GMM estimates reveal short-run contemporaneous positive effects of total asset turnover ratios on stock returns in levels. In view of the findings of this study, firms should strive to improve operating efficiency, among others, to enhance competitiveness and thereby to boost their stock prices for rewarding shareholders.
\end{abstract}

Keywords: stock returns, assets turnover, panel co-integration, ECM, DOLS, GMM.

\section{INTRODUCTION}

Total asset turnover ratio is calculated by dividing the total value of a company's sales revenue with the value of its total asset that includes physical assets, inventory and receivables. As a measure of efficiency, this is a key component of the DuPont analytical model beginning in the 1920s for rate of return on equity (ROE). The other two components are profitability and financial leverage. In the DuPont formula: ROE= profitability $\mathrm{x}$ asset utilization efficiency $\mathrm{x}$ financial leverage.

Businesses analyze total asset utilization ratios to determine how efficiently a firm operates relative to its competitors. They also separately analyze inventory and receivables turnovers to the same effect. The higher the ratios, operationally the more efficient the firm is than its competitors. In essence, total asset turnover ratio measures how efficiently a company manages its assets to generate larger sales. Moreover, total asset turnover ratio is linked to GDP growth, consumption growth, and industrial output expansion, but not so to investor sentiment. Higher total asset turnover ratios reflect a better state of affairs of the company, giving insights to the creditors and

\footnotetext{
* Assistant Professor of Accounting. McNeese State University, Lake Charles, LA 0609. Phone: 337-475-5564. E-mail: jwhite1@mcneese.edu.

† Professor of Finance. McNeese State University, Lake Charles, LA 70609. Phone: 337-4755577. E-Mail: mrahman@mcneese.edu.

\# Professor of Economics. South Carolina State University, Orangeburg, SC 29117. Phone: 803539-1194. E-Mail: mmustafa@scsu.edu.
} 
investors into the internal management of the company. A low total asset turnover ratio reveals excess production, bad inventory management and poor collection efforts. Usually, stocks of companies with high total asset ratios are undervalued and those of companies with low total asset turnover ratios are likely to be overvalued. These equity market anomalies inspire portfolio revision Thus, it is imperative for a company to improve this ratio. To do so, a company must focus on increasing sales revenue, improving inventory management, accelerating collection of accounts receivables, quickly liquidating obsolete or unused assets and leasing equipment instead of buying it since leased equipment is not counted as a fixed asset.

Profitable higher sales enhance total asset turnover ratio and generate higher profits enabling a company to offer higher reward to its shareholders. Within companies, managers can better utilize assets by being more efficient in using property, plant and equipment, collecting accounts receivables faster, and more streamlining the management of stockpiles. They need to do so because effective revenue generating total asset utilization really matters to shareholders. In general, a majority of companies that improve total asset turnover ratios offer higher total shareholder return (capital gain and dividend) than those with declining total asset turnover ratios. In other words, improved total asset utilization is typically beneficial for shareholders. However, this ratio and total shareholder return nexus can widely vary from one industry to another due to differences in their business models, required asset bases, ownership structures, capital structures, sectoral distributions, market structures, types of products and services, regulatory frameworks, etc. The goal of the current paper is not, however, to address the above specific issues.

A limited number of studies have recorded the impact of the asset turnover for the cross-section of stock returns and have dismissed it as being mimicked by other factors (e.g., Fairfield \& Yohn, 2001; Novy-Marx, 2013; and Esplin et al., 2014). Nissim and Penman (2001) argue that disaggregating financial statements into operating and financial activities is essential because operating activities mainly drive firm value.

The body of empirical studies on this topic is relatively small in the directly related existing literature. Moreover, the uses of advanced econometric techniques in this context are scant, to our knowledge. The goal is to gain additional insight into how important operating efficiency is for stock returns to reward company shareholders. Thus, we examine the impact of total asset turnover ratios on equity returns. A heterogeneous panel data set is used for analyses of 1961 US public companies of different industry-categories spanning over 2001-2015. Empirical methodologies applied in this study include Pedroni's panel co-integration and associated vector errorcorrection model estimation, dynamic ordinary least squares (DOLS) and generalized method of moments (GMM). The rest of the paper is organized as follows. Section II briefly reviews the related empirical literature. Section III outlines the empirical methodologies. Section IV reports results. Section V offers conclusions and managerial policy implications.

\section{BRIEF REVIEW OF RELATED EMPIRICAL LITERATURE}

The empirical literature on this topic, to our knowledge, is relatively scant. Firms cannot start or/and expand without assets (fixed, inventory, and accounts receivables) to produce their products. These assets measure firms' ability to survive and compete with other firms (Reyhani, 2012). On the other hand, there is strong relationship between the structure of assets and structure of capital. A firm cannot borrow money without a strong assets structure. Creditors prefer tangible assets when they decide to 
lend money (Campello \& Giambona, 2010). Firms hold assets because there is no effective market mechanism to sell and buy these assets. Some companies hold, especially, fixed assets for tax advantage to gear up economic growth and technology development (Dong et al., 2012).

Traditionally, there is a positive relationship between manufacturing companies' profitability and fixed assets, as they require a high percentage of fixed assets to transform raw materials into finished goods. For example, many firms in the mining sector have massive growths in fixed assets (Aguzzi \& Payne, 2007). The assets structure in the manufacturing companies also tends to increase investment in fixed assets and decrease investment in current assets. Moreover, the massive growth in fixed assets should lead to an increase in profit as long as total asset utilization improves production and sales (Kantudu, 2008). Li (2004) examines the negative association among capital investments in fixed assets, future profitability, and stock returns. This study analyzes the financial statements for a host of firms using data from 1962 to 2002. The results show a negative association between investment in fixed assets and future profitability.

Iqbal and Mati (2012) study the relationship between non-current assets and profitability of non-financial firms. They perform multiple regression analysis and conclude a direct association between non-current assets and profitability. Okwo et al. (2012) assess the impact of a company's investment in fixed assets on its operating profit margin. This study is based on a sample of companies in Nigeria for a period from 1999 to 2009. They use regression analysis to examine the relationship between level of investment in fixed assets and operating profit. The study finds a positive relationship between the above variables, though not statistically significant. Dhillon and Vachhrajani (2012) examine the impacts of operational efficiency on overall profitability of Gujarat power company limited (GIPCL), based on published data during June, 2005 - November, 2010. They use the activity ratios such as assets turnovers to measure the operational efficiency and overall profitability. The finding of the research indicates an insignificant positive correlation between operational efficiency and overall profitability.

Jamali and Asadi (2012) study the relationship between management efficiency and profitability of 13 auto manufacturing companies, listed on the Bombay stock Exchange for the period from 2006 to 2010. The asset turnover ratio is one of the most important ratios used in measuring the management efficiency. This study finds a high degree of correlation between profitability and management efficiency. Kotsina and Hazak (2012) examine the impact of investment intensity, measured by the percentage of fixed assets to total assets, and the return on assets. The sample size of the study includes 8,074 companies in six European union (EU) member countries over a nineyear period from 2001 to 2009. The finding of the study indicates no strong negative or no strong positive impact of companies' investment intensity on future rate of return on assets.

Ishmael and Kehinde (2013) examine the effects of components of current assets on the profitability of the Ajaokuta Iron Industry. The study observes different proportions of current assets in the industry with a huge amount of accounts receivables, relative cash, and bank deposits. The results reveal an uptrend in profitability during 2001-2010. Azadi (2013) examines the effect of changes in assets (fixed and current) on the operating earnings of the Tehran stock exchange. This study uses ordinary least squares (OLS) to investigate the above effects. Results show that for food and metal industries, the coefficient of variation of fixed assets has a positive and 
significant effect on operating earnings. For chemical industries, the coefficient of variation of current assets has no significant effect on operating earnings. In addition, the study suggests that the effects of changes in asset structure induce significant differences in operating assets across different industries.

The fixed assets are considered to have productive capacity in the manufacturing companies to generate sales and profit. On the other hand, these assets are considered as the base to generate and accumulate the current assets (Iqbal \& Mati, 2012). The manufacturing companies focus on the current assets because they convert these assets into cash to finance the operating activities (Ishmael \& Kehinde, 2013). In this area, these assets are playing a vital role to produce profit. This role can be measured by return on assets (ROA) and return on equity (ROE). ROA measures the net income generated from each currency unit invested in total assets and ROE indicates how well managers have used resources of shareholders to produce net income.

To measure efficiency of assets in generating profit, assets management ratios are used. These ratios are referred to as asset utilization or asset efficiency ratios for measuring a firm's ability to manage assets at its disposal. These ratios include accounts receivable turnover ratio, inventory turnover ratio, fixed asset turnover ratio and the total asset turnover ratio (Baker \& Powel, 2005). In general, there are three types of turnover: total assets turnover, fixed assets turnover and current assets turnover. They have differing effects on sales and profitability.

Past studies showed that asset utilization influences firm value in a positive way. Firms with high asset utilization ratio tend to expand their current capacity to meet prospective demand in the market (e.g., Ang et al., 2000; Iskandar et al., 2012). These studies argue that effective asset utilization will increase firm value, while ineffective asset utilization will decrease firm value.

Asset utilization as an organizational factor to determine financial performance of a company is based on the clarification of assets that are crucial to production or service processes necessary to drive the financial performance (Belanova, 2016). The consideration of asset utilization is significant towards identifying and measuring capability and different functions of these assets by a company in ensuring the attainment of financial returns (Ellis, 1998). When assets are not effectively and efficiently utilized, they lead to poor financial performance.

According to Fleming et al. (2005) agency costs are likely to increase when assets are inefficiently and ineffectively utilized. This is an indication of management not promoting the interests of the business owners. A study by Okwo et al. (2012) on fixed assets investment and profitability of a company indicates a positive relationship between the above variables. $\mathrm{Xu}$ and $\mathrm{Xu}$ (2013) examine the significance of achieving business performance from an optimal allocation of assets structure point of view. They find a significant positive correlation between the business performance and optimal allocation of asset structure. Moreover, Jose et al. (2011) find a significant positive effect of efficient and effective utilization of assets on the financial performance of a company.

\section{EMPIRICAL METHODOLOGIES}

A heterogeneous panel data-set as a combination of cross-sectional and time series observations is used in this study. This provides a convenient way to study phenomenon where a statistically adequate number of cross-sectional and time series observations are not available. This improves both quality and quantity of data-set. Otherwise, it would be impossible to use only one of these two dimensions for 
meaningful analyses (Gujarati, 2003). This study provides an example of such situation where incorporating observations on the variables over successive time periods allows expansion of the informational content of the data. Furthermore, since the length of the time series is small compared to the number of cross-sections, the effects of autocorrelation are small if not negligible. Panel data estimation models include the constant coefficient (pooled), the fixed effects and the random effects regression models.

In order to test for the existence of long-run equilibrium relationship between variables in a heterogeneous panel, the following model is specified:

$$
y_{i t}=\alpha_{i}+\beta_{i} x_{i t}+\gamma_{t} D_{i t}+e_{i t}
$$

Where:

$y=$ stock return.

$x=$ total asset turnover ratio.

Both variables are in levels.

$\mathrm{i}=1, \ldots ., \mathrm{N}$.

$\mathrm{t}=1, \ldots ., \mathrm{T}$.

The panel data set, thus, has altogether $\mathrm{N}^{*} \mathrm{~T}$ observations. Annual financial information for companies is obtained from COMPUSTAT, and stock returns are obtained from CRSP. For a company to be included in our sample, it must have sales, total assets, and stock return information for all years from 2001-2015.

In Model (1), $\alpha_{i}$ shows the possibility of company-specific fixed effects and $\beta_{i}$ allows for heterogeneous co-integrating vectors. $\gamma_{t}$ represents time-dependent common shocks, captured by common-time dummies $\left(D_{i t}\right)$, that might simultaneously affect all 1961 companies included in this study. Model (1) is estimated by the proposed Pedroni $(2000,2001)$ panel fully-modified ordinary least squares (FMOLS) co-integration technique, which adjust for the presence of endogeneity and serial correlation in the data. This method is an appropriate technique, especially if there are endogenous macroeconomic factors that can cause co-movements in the above variables.

Prior to estimating Model (1), it is required that non stationarity and the order of integration of the variables are determined by using panel unit root tests. If all variables are found to be I (1), then by using the Pedroni's panel co-integration tests $(1999,2000$, and 2001), it is investigated whether they are co- integrated. The aforementioned tests and techniques are warranted to make sure that no spurious regression phenomenon exists in the estimation of $\beta_{i}$. In order to test for the presence of a unit root in the panel data series under study, panel unit root tests proposed by Breitung (2000), Levin et al. (2002), and Im et al. (2003) are employed. For all these tests, the null hypothesis is nonstationarity of both variables in levels.

Subsequently, the following panel vector error- correction model in the spirit of (Engle \& Granger, 1987) is estimated on the evidence of co-integrating relationship between the variables of interest:

$$
\Delta y_{i t}=\alpha+\sum_{q=1}^{k} \beta i \Delta y_{i t-q}+\sum_{q=1}^{l} \phi i \Delta x_{i t-q}+\pi \hat{e}_{i t-1}+\mu_{i t}
$$

For long-run convergence and causal relationship, the estimated coefficient $(\hat{\pi})$ of the error-correction term $\left(\hat{e}_{i t-1}\right)$ is expected to be negative. The associated high pseudo t-value indicates its statistical significance. The estimated $\beta_{\mathrm{i}}$ and $\phi_{\mathrm{i}}$ reveal shortrun interactive feedback relationships. The appropriate lag-lengths are determined by the Akaike (1969) information criterion (AIC).

Intuitively, when the variables are co-integrated, then in the short term, deviations from this long-term equilibrium will feed back on the changes in 
the dependent variable in order to force the movement towards the long-term equilibrium. If the dependent variable is driven directly by this long-term equilibrium error, then it is responding to this feedback. If not, it is responding only to short-term shocks to the stochastic environment. The significance tests of the 'differenced' explanatory variables give an indication of the 'short-term' effects, whereas the longterm' causal relationship is implied through the significance in terms of the associated pseudo t-value of the lagged error-correction term, which contains the long-term information since it is derived from the long-term co-integrating relationship. The coefficient of the lagged error-correction term, however, is a short-term adjustment coefficient and represents the proportion by which the long-term disequilibrium (or imbalance) in the dependent variable is being corrected in each short period. Non-significance or elimination of any of the 'lagged error-correction term' affects the implied long-term relationship and may be a violation of theory.

Next, dynamic OLS (DOLS) is applied following Stock and Watson (1993). This procedure is more appropriate for small samples to estimate parameters than other alternatives (e.g., Engle \& Granger, 1987; Phillips \& Hansen, 1990.)

Finally, this study also invokes panel generalized method of moments (GMM), as developed in Hansen (1982), for robust and efficient estimates. GMM is one of the most widely used econometric tools in finance. A set of moment conditions is used to estimate model parameters by GMM. In general, the number of moment conditions is larger than the number of model parameters. A model misspecification for overidentification restrictions can be tested by GMM J-statistic. GMM does not require strong distributional assumptions for applications in finance. Since this paper employs panel data, GMM dynamic panel estimation is more appropriate than the original GMM estimation. On differencing of the regression equation, company- specific unobserved effects and the use of differenced lagged regressors eliminate parameter inconsistency arising from simultaneity bias (Arellano \& Bond, 1991). Monte Carlo simulations of the model offer dramatic improvements in both efficiency and consistency (Blundell \& Bond, 1998).

\section{RESULTS}

To ascertain the property of non-stationarity/stationarity of each variable in the heterogeneous panel data set, the panel unit root tests results are reported as follows:

Table 1

Panel Unit Root Tests*

\begin{tabular}{cccc}
\hline & Method & & \\
\hline Variables (Level) & LLC & Breitung & IPS \\
\hline SMR & -129.49 & -43.3860 & -63.9305 \\
& $(0.001)$ & $(0.003)$ & $(0.001)$ \\
SAT & -127.497 & -42.3541 & -629.582 \\
& $(0.002)$ & $(0.003)$ & $(0.004)$ \\
\hline Variables (Difference) & LLC & Breitung & IPS \\
\hline SMR & -214.257 & -59.0305 & 155.607 \\
& $(0.001)$ & $(0.002)$ & $(0.001)$ \\
SAT & 211.658 & -58.242 & -115.521 \\
& $(0.001)$ & $(0.002)$ & $(0.001)$ \\
\hline
\end{tabular}

${ }^{*}$ Associated P-values are reported within parentheses for the exact levels of significance. 
Here, $\mathrm{SMR}=$ stock return, and $\mathrm{SAT}=$ company sale/total asset. To note, $\mathrm{LLC}=$ Levin, Lin, and Chu (2002) test, and IPS= Im, Pesaran and Shin (2003) test. The variables are asymptotically distributed as standard normal distributions with a lefthand side rejection area. Associated P-value indicates the failure of rejection of null hypothesis of non-stationarity at the exact level of significance. $\mathrm{N}=1961, \mathrm{~T}=15$ years and $(\mathrm{NT})=23,532$.

In Table 1, LLC, Breitung and IPS tests for panel unit root reveal that the null hypothesis of unit root for both variables cannot be rejected at 5 percent level of significance. In other words, the variables are nonstationary in levels. Moreover, each variable becomes stationary on firs-differencing depicting I (1) behavior.

On the evidence for non-stationarity and I (1) behavior, a battery of seven panel co-integration tests are reported as follows:

Table 2

Panel Co-integration Tests*

\begin{tabular}{lcc}
\hline \multicolumn{2}{l}{ Null Hypothesis: No Co-integration } & \\
\cline { 2 - 3 } Panel v-Statistic & Statistic & P-Value \\
Panel rho-Statistic & -38.90985 & 0.008 \\
Panel PP-Statistic & -8.992718 & 0.003 \\
Panel ADF-Statistic & -123.0594 & 0.007 \\
\hline & -54.51130 & 0.010 \\
Group rho-Statistic & Statistic & P-Value \\
Group PP-Statistic & 10.18753 & 0.005 \\
Group ADF-Statistic & -148.6691 & 0.010 \\
\hline
\end{tabular}

${ }^{*}$ Associated P-value shows failure to reject null hypothesis at the exact level of significance.

As observed above, Panel V-Statistic, Panel PP-Statistic and Panel ADF-Statistic reject the null hypothesis of no co-integration at 5 percent level of significance or more except the panel rho-statistic. So, out of seven tests, six tests to this effect confirm cointegrating relationship between the variables.

As stated above, the bi-variate panel error-correction model is subsequently estimated. The results are reported as follows:

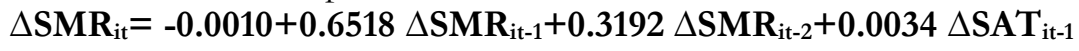

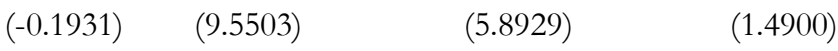

$$
\begin{aligned}
& +\mathbf{0 . 0 0 1 6} \Delta \mathrm{SAT}_{\mathrm{it}-2-0.640} \widehat{\mathrm{e}}_{\mathrm{it}-1} \\
& \begin{array}{ll}
(0.9636) \quad(-2.1780) \\
\hline
\end{array} \\
& \overline{\mathrm{R}}^{2}=0.3226, \mathrm{AIC}=2.3218
\end{aligned}
$$

In equation (2)' that corresponds to equation (2), the coefficient of the estimated error-correction term $\left(\hat{\mathrm{e}}_{\mathrm{it}-1}\right)$ has the expected negative sign, although its numerical magnitude is below unity. However, its associated pseudo t-value is significant. Together, they suggest convergence of the variables at a moderate pace toward longrun equilibrium. The effects of changes in prior stock market returns and total asset turnover ratios with two-period lags are positive. The optimum lag-lengths are determined by the AIC that is computed low at $2.3218 . \overline{\mathrm{R}}^{2}$ shows that 32.26 percent of the current change in the stock return in the panel data set is due to lagged changes in the variables that are included in (2)'. 
Subsequently, the DOLS and the GMM estimates are reported in Tables 3 and 4, respectively as follows:

Table 3

DOLS Estimates

\begin{tabular}{ccccc}
\hline \multicolumn{2}{|c}{ Dependent variable: $\mathrm{SMR}_{\text {it }}$} & & & \\
\hline Variable & Coefficient & Std. Error & t-Statistic & P-value \\
\hline SAT $_{\text {it }}$ & 0.048574 & 0.001874 & 25.92706 & 0.001 \\
\hline
\end{tabular}

$\overline{\mathrm{R}}^{2}=0.0263, \mathrm{AIC}=2.3816$

The DOLS estimates in levels without lag in a static framework show that total asset turnover ratios have positive impact on stock returns. The associated t-value of the slope coefficient is overly high and also significant at 1 percent level in term of the associated P-value. $\overline{\mathrm{R}}^{2}$ indicates 2.63 percent explanatory power of the model. Also AIC value is low at 2.3816 to ensure no over-parameterization of the model for efficiency and unbiasedness of the estimated parameters in an a temporal setting.

Table 4

GMM Estimates

\begin{tabular}{ccccc}
\hline \multicolumn{2}{l}{ Dependent variable: SMR $_{\text {it }}$} & & & \\
\hline Variable & Coefficient & Std. Error & t-Statistic & P-value \\
\hline SAT $_{\text {it }}$ & 0.016445 & 0.001313 & 12.52580 & 0.002 \\
\hline \hline $\mathbf{R}^{2}=0.0326$ &
\end{tabular}

$\overline{\mathrm{R}}^{2}=0.0326, \mathrm{AIC}=1.9826$

Similarly, GMM estimates reveal positive impact of total asset turnover ratios on stock returns in levels in a panel data set. Again, the associated t-value of the estimated slope coefficient is quite high but less than that in the preceding table. The associated P-value indicates significance exactly at 2 percent level. $\overline{\mathrm{R}}^{2}$ shows 3.26 percent explanatory power of the estimated model and the AIC-value is relatively lower at 1.9826 ensuring efficiency and unbiasedness of the estimated parameters by avoiding over-parameterization of the model.

\section{CONCLUSIONS AND MANAGERIAL IMPLICATIONS}

Individual stock returns and total asset turnover ratios in the heterogeneous panel of 1961 US public firms from 2001 to 2015 are non-stationary in levels with I (1) behavior. Both variables are found co-integrated in levels. The estimates of the bivariate ECM suggest convergence of the variables toward long-run equilibrium at moderate pace. The lagged variables in the estimated ECM disclose short-run interactive positive feedback effects. The estimates of both DOLS and GMM exert positive effects of total asset turnover ratios on stock returns in levels, though subdued.

In light of the above findings, to boost stock prices for rewarding shareholders, firms should improve internal managerial efficiency, among others. To increase total asset turnover ratios, they should effectively utilize physical infrastructure to generate additional income, adopt just-in-time approach to manage inventory, lessen use of assets to generate certain level of profitable sales, expedite collection of accounts receivables, and ensure capital discipline. A company should exercise discipline and prudence in how much money it borrows, raises and spends, in order to deliver the best sustainable returns to its shareholders. At the same time, shareholders ought to press for tighter capital discipline emphasizing value rather than volume and leasing physical assets since they are not recorded as asset in a company's balance sheet. To add further, a company can perform better on this metric by decreasing the amount of assets to 
achieve a certain level of sales. In closing, for further extension of the paper, impacts of individual turnover ratios of various components of total asset on stock price should be taken into account because their effects on stock prices are likely to be asymmetric. This is one of the remaining shortcomings of the current study.

\section{REFERENCES}

Aguzzi, A., \& Payne, C. (2007). Assets performance management drives mining profitability: Increasing coal production without significant capital investment. Retrieved February 14, 2019 from http://www.ivara.com/content/pdfs/Mining-Innovation-USCCG.

Akaike, H. (1969). Fitting autoregressive for prediction. Annuls of the Institute of Statistical Mathematics, 21(1), 243-247.

Ang, J. S., Cole, R. A., \& Lin, W. J. (2000, February). Agency cost and ownership structure. Journal of Finance, 55(1), 81-106.

Arellano, M., \& Bond, S. (1991, April). Some tests of specification for panel data: Monte Carlo evidence and an application to employment equations. The Review of Economic Studies, 58(2), 277-297.

Azadi, M. (2013). The relationship between changes in asset structure and operating earnings in the Tehran Stock Exchange (TSE). Trends in Advanced Science \& Engineering (TASE), 7(1), 30-34.

Baker, H. K., \& Powell, G. E. (2005). Understating financial management: A practical guide. Blackwell Publishing: United Kingdom.

Belanova, K., (2016, April). The impact of national environment of a company on its financial policy. International Journal of Management Science \& Business Administration, 2(5), 32-37.

Blundell, R. \& Bond, S. (1998). Initial conditions and moment restrictions in dynamic panel data models. Journal of Econometrics, 87(1), 115-143.

Breitung, J. (2000). The local power of some unit root tests for panel data. Advances in Econometrics, 15, 161-177.

Campello, M., \& Giambona, E. (2010). Asset tangibility and capital structure. Retrieved March 18, 2019 from http://www.eds.edu/fileadmin/redakteur/ funkt.dept.../1003232_Giambona.pdf.

Dhillon, A. S., \& Vachhrajani, H. (2012). Impact of operational efficiency on overall profitabilityA case study of GIPCL. Retrieved March 20, 2019 from http://zmrita.edu/asb/pdfs/wrokingpaper.

Dong, Y. 1., Charles, K. Y., \& Cai, D. (2012). What drives fixed asset holding and riskadjusted performance of corporates in China? An empirical analysis. International Real Estate Review, 15(2), 141-164.

Ellis, R. (1998). Asset utilization: A metric for focusing Reliability Efforts (7th ed.) Marriott Houston Westside: Gulf Publishing Company.

Engle, R. F., \& Granger, C. W. J. (1987, March). Co-integration and error correction: representation, estimation and testing. Econometrica, 55(2), 251-276.

Esplin, A. M., Hewitt, M. P., \& Yohn, T. (2014). Disaggregating operating and financial activities: Implications for forecasts of profitability. Review of Accounting Studies, 19(1), 328-362.

Fairfield, P. M. \& Yohn, T. (2001). Using asset turnover and profit margin to forecast changes in profitability. Review of Accounting Studies, 6(4), 371-385.

Fleming, G. A., Heaney, R. A., \& McCosker, R. (2005). Agency cost and ownership structure in Australia. Pacific-Basin Finance Journal, 13(1), 29-52. 
Gujarati, D. N. (2003). Basic economics (4th ed.). McGraw-Hill, New York.

Hansen, L. P. (1982). Large sample properties of generalized method of moments estimators. Econometrica (Journal of The Econometric Society), 50(4), 1029-1054.

Im, K. S., Pesaran, M. H., \& Shin, Y. (2003). Testing for unit roots in heterogeneous panels. Journal of Econometrics, 115, 53-74.

Iqbal, A., \& Mati, M. (2012). Relationship between non-current assets and firms profitability. Retrieved March 20, 2019 from http://mpra.ub.uni-muenchen.de/ 44132/MPRA.

Ishmael, O., \& Kehinde, J. S. (2013). Profitability analysis trend of components of current assets and their prospects in Ajaokuta iron industry. Canadian Journal of Accounting \& Finance, 1(2), 28-37.

Iskandar, T. M., Bukit, R. B., \& Sanusi, Z. M. (2012). The moderating effect of ownership structure on the relationship between free cash flow and asset utilization. Asian Academy of Management Journal of Accounting \& Finance, 8(1), 6989.

Jamali, A. H., \& Asadi, A. (2012). Management efficiency and profitability in Indian automobile industry: From theory to practice. Indian Journal of Science \& Technology, 5(5), 2779-2781.

Jose, M. L., Lancaster, C., \& Stevens, J. L. (2011). Stability of excellence: Revealed patterns in Tobin's Q-ratios. Journal of Applied Business Research, 12(2), 83-91.

Kantudu, A. S. (2008, March 24). Effect of profitability and total assets on the funded status of pension assets of quoted firms in Nigeria (pp. 1-22). Retrieved from http:/ / ssrn.com/=1104845.

Kotsina, S., \& Hazak, A. (2012). Does investment intensity impact company profitability? A crosscountry empirical study. Proceedings from the $2^{\text {nd }}$ International Conference of Economics, Trade and Development IPEDR, 36, IACSIT Press, Singapore.

Levin, A., Lin, C. F., \& Chu, C. (2002). Unit root tests in panel data: Asymptotic and finite sample properties. Journal of Econometrics, 108, 1-24.

Li, D. (2004, January). The implications of capital investments for future profitability and stock. returns-an overinvestment perspective (pp. 1-55). Retrieved March 20, 2019 from http://bschool.nus.edu/departments/FinanceandAccounting/Donglinli.

Nissim, D., \& Penman, S. H. (2001). Ratio analysis and equity valuation: From research to practice. Review of Accounting Studies, 6(1), 109-154.

Novy-Marx, R. (2013). The other side of value: The gross profitability premium. Journal of Financial Economics, 108(1), 1-28.

Okwo, I. M., Okelue, U. D., \& Nweze, A. U. (2012). Investment in fixed assets and firm profitability: Evidence from the Nigerian brewery industry. European Journal of Business \& Management, 4(20), 10-17.

Pedroni, P. (2000). Fully modified OLS for heterogeneous cointegrated panels. Advanced in Econometrics, 15, 93-130.

Pedroni, P. (2001). Purchasing power parity tests in cointegrated panels. Review of Economics \& Statistics, 83(4), 727-731.

Phillips, P. C. B., \& Hansen, B. E. (1990, January). Statistical inference in instrumental variables regression with I (1) processes. The Review of Economic Studies, 57(1), 99125.

Reyhani, A. G. (2012). The investigation of effect of assets structure on performance of accepted companies of Tehran Stock Exchange (TSE). Journal of Basic \& Applied Scientific Research, 2(2), 1086-1090. 
Stock, J. H., \& Watson, M. W. (1993, July). A simple estimator of cointegrating vectors in higher order integrated systems. Econometrica, 61(4), 783-820.

Xu, Z. S., \& Xu, N. Z. (2013, September 15). Research on the optimal allocation of assets structure and corporation management performance: A case study of China Textile Machinery Co., Ltd. Asian Journal of Business Management, 5(4), 332338. 